\title{
Statistical optimization of medium components for biosurfactant production by Achromobacter xylos GSR21
}

\author{
Golamari Siva Reddy, Kamma Srinivasulu, Botlagunta Mahendran, \\ Ronda Srinivasa Reddy
}

Centre for Bioprocess Technology, Department of Biotechnology, Koneru Lakshmaiah Education Foundation

(Deemed to be University), Green Fields, Vaddeswaram, Guntur, Andhra Pradesh, India

\begin{abstract}
Introduction: Biosurfactants have picked up an impressive consideration as of late due to their potential uses in an expansive scope of use territories, including environmental remediation, agriculture, biofilm formation, quorum sensing, textile, pharmaceuticals, cosmetics, and the food, oil, and petrochemical industries. Aim: In the present study, optimization of the critical medium components for biosurfactant production by Achromobacter xylos strain GSR21 using statistical experimental design was studied. Materials and Methods: Response surface methodology (RSM) was employed to determine the optimal level of the four medium variables (agar powder, yeast extract, $\mathrm{FeSO}_{4} 7 \mathrm{H}_{2} \mathrm{O}$, and $\mathrm{KH}_{2} \mathrm{PO}_{4}$ ). Central composite design of $\mathrm{RSM}$ was applied to study the four variables at five levels, and biosurfactant concentration was measured as a response. Results: Regression coefficients were calculated by regression analysis and the model equation was determined. $\mathrm{R}^{2}$ value for biosurfactant $(\mathrm{g} / \mathrm{L})$ was calculated as $72 \%$, and it indicates that the model was well fitted with the experimental results. Surface plots were made, and the maximum biosurfactant production (A. xylos strain GSR21) $(10.20 \mathrm{~g} / \mathrm{L})$ was predicted at the optimized values of agar powder $90 \mathrm{~g} / \mathrm{L}$, yeast extract $5 \mathrm{~g} / \mathrm{L}, \mathrm{FeSO}_{4} 7 \mathrm{H}_{2} \mathrm{O} 0.05 \mathrm{~g} / \mathrm{L}$, and $\mathrm{KH}_{2} \mathrm{PO}_{4} 0.15 \mathrm{~g} / \mathrm{L}$. The obtained mathematical model was verified by performing the experiment with the predicted optimized values, and the yield of bio-surfactant was found to be $9.69 \mathrm{~g} / \mathrm{L}$. Validation of the predicted model was fitted $96.9 \%$ with the experimental results conducted at the optimum conditions. Conclusion: Results of this statistical analysis showed that agar powder and yeast extract had found significant medium components for biosurfactant (A. xylos GSR21) production.
\end{abstract}

Key words: Achromobacter xylos, biosurfactant, central composite design, response surface methodology

\section{INTRODUCTION}

$\mathrm{S}$ urfactants are generally natural intensifies that are amphiphilic in nature containing both hydrophobic and hydrophilic gatherings, and it is utilized to bring down the interfacial tension between two fluids. ${ }^{[1-3]}$ Surfactants may go about as detergents, wetting, emulsifiers, foaming agents, and dispersants. ${ }^{[4]}$ Biosurfactants got from microorganisms are observed to be better interchange for the synthetic surfactants. They are complex particles that can be grouped in light of various structures that incorporate lipopeptides, glycolipids, polysaccharideprotein buildings, unsaturated fats, and phospholipids. ${ }^{[5]}$ The real points of interest of utilizing biosurfactants are biodegradability, low toxicity and can be created from inexhaustible and less expensive substrates. ${ }^{[6]}$ Biosurfactants are fundamentally utilized for bioremediation to treat hydrocarbon contaminated destinations and furthermore for oil recuperation. They are likewise utilized as one of the fixings in the definition of pesticides, medicinal services, and beautifiers, mash and paper, and nourishment ventures. ${ }^{[7,8]}$ Microorganisms, for example, Bacillus subtilis, Bacillus licheniformis, Bacillus pumilis, and Pseudomonas putida are equipped for delivering biosurfactant. ${ }^{[9-12]}$ Lipopeptides got

\section{Address for correspondence: \\ Ronda Srinivasa Reddy, Department of Biotechnology, Centre for Bioprocess Technology, Koneru Lakshmaiah Education Foundation (Deemed to be University), Green Fields, Vaddeswaram, Guntur - 522 502, Andhra Pradesh, India. E-mail: siva_bt@kluniversity.in}

Received: 20-06-2018

Revised: 20-09-2018

Accepted: 17-11-2018 
Table 1: Range of variable levels for RSM experiment

\begin{tabular}{llccccc} 
Factors (g/L) & Symbol & $\mathbf{2}$ & $\mathbf{1}$ & $\mathbf{0}$ & $\mathbf{- 1}$ & $\mathbf{- 2}$ \\
\hline Agar powder & A & 70 & 60 & 50 & 40 & 30 \\
Yeast extract & B & 7 & 6 & 5 & 4 & 3 \\
$\mathrm{FeSO}_{4} \cdot 7 \mathrm{H}_{2} \mathrm{O}$ & $\mathrm{C}$ & 0.06 & 0.055 & 0.05 & 0.045 & 0.04 \\
$\mathrm{KH}_{2} \mathrm{PO}_{4}$ & $\mathrm{D}$ & 0.25 & 0.2 & 0.15 & 0.1 & 0.05 \\
\hline
\end{tabular}

RSM: Response surface methodology

Table 2: Central composite design matrix with the experimental and predicted values of biosurfactant produced by Achromobacter xylos strain GSR21

\begin{tabular}{|c|c|c|c|c|c|c|c|}
\hline \multirow[t]{2}{*}{ Run order } & \multicolumn{4}{|c|}{ Medium components } & \multicolumn{3}{|c|}{ Biosurfactant (g/L) } \\
\hline & A & B & C & D & Experimental & Predicted & Residual \\
\hline 1 & 30 & 3 & 0.04 & 0.05 & 7.33 & 7.98 & -0.65 \\
\hline 2 & 70 & 3 & 0.04 & 0.05 & 8.53 & 9.79 & -1.26 \\
\hline 3 & 30 & 7 & 0.04 & 0.05 & 8.67 & 9.34 & -0.67 \\
\hline 4 & 70 & 7 & 0.04 & 0.05 & 9.33 & 8.26 & 1.07 \\
\hline 5 & 30 & 3 & 0.06 & 0.05 & 5.33 & 5.33 & 0.00 \\
\hline 6 & 70 & 3 & 0.06 & 0.05 & 9.33 & 7.98 & 1.35 \\
\hline 7 & 30 & 7 & 0.06 & 0.05 & 7.33 & 6.63 & 0.70 \\
\hline 8 & 70 & 7 & 0.06 & 0.05 & 5.33 & 6.38 & -1.05 \\
\hline 9 & 30 & 3 & 0.04 & 0.25 & 5.33 & 5.08 & 0.25 \\
\hline 10 & 70 & 3 & 0.04 & 0.25 & 7.33 & 7.73 & -0.40 \\
\hline 11 & 30 & 7 & 0.04 & 0.25 & 6.58 & 7.62 & -1.04 \\
\hline 12 & 70 & 7 & 0.04 & 0.25 & 6.57 & 7.37 & -0.80 \\
\hline 13 & 30 & 3 & 0.06 & 0.25 & 4.55 & 5.32 & -0.77 \\
\hline 14 & 70 & 3 & 0.06 & 0.25 & 8.67 & 8.80 & -0.13 \\
\hline 15 & 30 & 7 & 0.06 & 0.25 & 8.25 & 7.79 & 0.46 \\
\hline 16 & 70 & 7 & 0.06 & 0.25 & 9.33 & 8.38 & 0.95 \\
\hline 17 & 10 & 5 & 0.05 & 0.15 & 8.53 & 7.92 & 0.61 \\
\hline 18 & 90 & 5 & 0.05 & 0.15 & 10.2 & 10.32 & -0.12 \\
\hline 19 & 50 & 1 & 0.05 & 0.15 & 6.35 & 5.79 & 0.56 \\
\hline 20 & 50 & 9 & 0.05 & 0.15 & 6.67 & 6.73 & -0.06 \\
\hline 21 & 50 & 5 & 0.03 & 0.15 & 8.67 & 7.17 & 1.50 \\
\hline 22 & 50 & 5 & 0.07 & 0.15 & 4.53 & 5.53 & -1.00 \\
\hline 23 & 50 & 5 & 0.05 & -0.05 & 8.67 & 8.66 & 0.01 \\
\hline 24 & 50 & 5 & 0.05 & 0.35 & 8.25 & 7.76 & 0.49 \\
\hline 25 & 50 & 5 & 0.05 & 0.15 & 7.33 & 8.04 & -0.71 \\
\hline 26 & 50 & 5 & 0.05 & 0.15 & 9.33 & 8.04 & 1.29 \\
\hline 27 & 50 & 5 & 0.05 & 0.15 & 7.33 & 8.04 & -0.71 \\
\hline 28 & 50 & 5 & 0.05 & 0.15 & 8.25 & 8.04 & 0.21 \\
\hline 29 & 50 & 5 & 0.05 & 0.15 & 7.33 & 8.04 & -0.71 \\
\hline 30 & 50 & 5 & 0.05 & 0.15 & 8.67 & 8.04 & 0.63 \\
\hline
\end{tabular}

from B. subtilis are especially intriguing a result of their high surface action and restorative potential. ${ }^{[13,14]}$

Optimization of medium and fermentation conditions is a basic advance in bioprocess improvement, and it includes a few variables. ${ }^{[15]}$ One factor at a time optimization is accepted method; however, it has numerous weaknesses such as more trial runs and time. ${ }^{[16]}$ Response surface method (RSM) is an accumulation of measurable devices to outline and examinations the analyzes concentrated 
Table 3: ANOVA statistics for biosurfactant production by Achromobacter xylos GSR21

\begin{tabular}{|c|c|c|c|c|c|c|}
\hline Factors & Sum of squares & df & Mean squares & F value & $p$-value & Significance \\
\hline Model & 48.10 & 14 & 3.44 & 2.79 & 0.0292 & Significant \\
\hline A-Agar powder & 8.63 & 1 & 8.63 & 6.99 & 0.0184 & Significant \\
\hline B-Yeast extract & 1.32 & 1 & 1.32 & 1.07 & 0.3172 & \\
\hline C- $\mathrm{FeSO}_{4} \cdot 7 \mathrm{H}_{2} \mathrm{O}$ & 4.03 & 1 & 4.03 & 3.26 & 0.0909 & Significant \\
\hline D- $\mathrm{KH}_{2} \mathrm{PO}_{4}$ & 1.22 & 1 & 1.22 & 0.99 & 0.3359 & \\
\hline$A B$ & 8.40 & 1 & 8.40 & 6.81 & 0.0198 & Significant \\
\hline$A C$ & 0.70 & 1 & 0.70 & 0.57 & 0.4625 & \\
\hline$A D$ & 0.69 & 1 & 0.69 & 0.56 & 0.4651 & \\
\hline $\mathrm{BC}$ & 0.00 & 1 & 0.00 & 0.00 & 0.9523 & \\
\hline $\mathrm{BD}$ & 1.39 & 1 & 1.39 & 1.12 & 0.3058 & \\
\hline CD & 8.31 & 1 & 8.31 & 6.74 & 0.0203 & Significant \\
\hline $\mathrm{A}^{\wedge} 2$ & 1.99 & 1 & 1.99 & 1.61 & 0.2235 & \\
\hline $\mathrm{B}^{\wedge} 2$ & 5.42 & 1 & 5.42 & 4.39 & 0.0535 & Significant \\
\hline $\mathrm{C}^{\wedge} 2$ & 4.88 & 1 & 4.88 & 3.96 & 0.0652 & Significant \\
\hline $\mathrm{D}^{\wedge} 2$ & 0.05 & 1 & 0.05 & 0.04 & 0.8420 & \\
\hline Residual & 18.50 & 15 & 1.23 & & & \\
\hline Lack of fit & 14.89 & 10 & 1.49 & 2.06 & 0.2203 & Not significant \\
\hline Pure error & 3.62 & 5 & 0.72 & & & \\
\hline Cor total & 66.61 & 29 & & & & \\
\hline
\end{tabular}

ANOVA: Analysis of variance

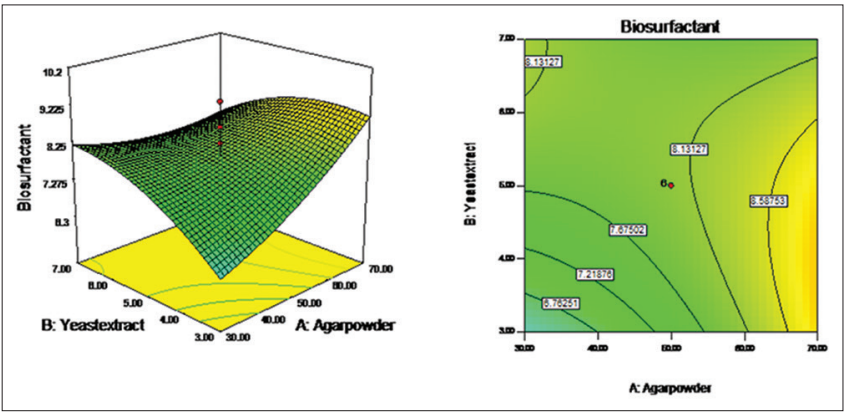

Figure 1: Three-dimensional and contour surface plots showing the mutual effect between pair of variables agar powder (A) and yeast extract (B) on biosurfactant production

on improvement. ${ }^{[17]}$ RSM is effectively utilized to decide the ideal states of the chose factors associated with the procedure. ${ }^{[9,18,19]}$ The fundamental preferred standpoint of utilizing RSM is to assess the cooperation impact of the factors under investigation with the assistance of reaction surface plots produced by the product.

The objective of this study is to determine the optimal levels of the medium components for biosurfactant production from Achromobacter xylos strain GSR21 by RSM.

\section{MATERIALS AND METHODS}

\section{Microorganism}

The microorganism A. xylos GSR21 used in this study was obtained from Environmental Microbiology Laboratory culture collection of the Department of Biotechnology at K L University Andhra Pradesh, India. The culture was maintained in Luria Bertani (LB) Agar plates incubated at $30^{\circ} \mathrm{C}$ and subcultured at regular intervals. Inoculums were prepared by transferring a loopful of culture to $100 \mathrm{~mL}$ of sterilized LB broth and kept in a rotary shaker incubator at $200 \mathrm{rpm}$ at $30^{\circ} \mathrm{C}$ for $48 \mathrm{~h}$. All the chemicals used in the study are of analytical grade and procured from quality-control, Hyderabad, India.

\section{Fermentation Conditions}

Nearly $2 \%(\mathrm{~W} / \mathrm{V})$ of the seed culture was inoculated in the production media containing $(\mathrm{g} / \mathrm{L})$ : Glycerol, $5 \mathrm{~g}$; asparagine $1 \mathrm{~g} ; \mathrm{KH}_{2} \mathrm{PO}_{4}, 1 \mathrm{~g} ; \mathrm{MgSO}_{4} .7 \mathrm{H}_{2} \mathrm{O}, 5 \mathrm{~g} ; \mathrm{KCl}, 1.0 \mathrm{~g}$; agar powder, $15 \mathrm{~g}$; and $1 \mathrm{~mL}$ of trace solution containing (in $1 \mathrm{~L}$ of distilled water) $\mathrm{MgSO}_{4} \cdot 7 \mathrm{H}_{2} \mathrm{O}, 0.5 \mathrm{~g}, \mathrm{CuSO}_{4} \cdot 5 \mathrm{H}_{2} \mathrm{O}, 0.16 \mathrm{~g}$, and $\mathrm{FeSO}_{4} \cdot 7 \mathrm{H}_{2} \mathrm{O}, 0.015 \mathrm{~g}$. The initial $\mathrm{pH}$ of the medium was 
adjusted to $8.0 .{ }^{[20]}$ All fermentations were carried out at $30^{\circ} \mathrm{C}$ in shaker flask held on a rotary platform shaker at $200 \mathrm{rpm}$. For statistical optimization experiments, $100 \mathrm{~mL}$ of medium was prepared in $250 \mathrm{~mL}$ conical flask according to the central composite design (CCD) given in Table 1.

\section{Biosurfactant Precipitation}

About $1.5 \mathrm{~mL}$ of fermented broth was collected in $2 \mathrm{~mL}$ Eppendorf tube and centrifuged at 10,000 rpm for $10 \mathrm{~min}$. After centrifugation, the supernatant was used for the extraction of biosurfactant. $6 \mathrm{~N} \mathrm{HCl}$ was added in the Eppendorf containing supernatant and kept it for overnight incubation. Then, the sample was centrifuged at $6000 \mathrm{rpm}$ for $10 \mathrm{~min}$, and the precipitated biosurfactant was collected in the form of pellet. The precipitated biosurfactant was dried in hot air oven at $80^{\circ} \mathrm{C}$ for overnight and weight of the crude biosurfactant was determined.

\section{Experimental Design}

Fourmedium variables (agar powder, yeast extract, $\mathrm{FeSO}_{4} \cdot 7 \mathrm{H}_{2} \mathrm{O}$, and $\mathrm{KH}_{2} \mathrm{PO}_{4}$ ) were selected for RSM optimization studies based on preliminary screening studies. The range of the level of four variables was given in Table 1.30 experiments were carried out according to CCD shown in Table 2. The relationship between the variables and the response is generally represent by the second order polynomial equation (Eqn. 1).

$$
Y=\begin{aligned}
& \dot{a}_{0}+\dot{a}_{1} X_{1}+\dot{a}_{2} X_{2}+\dot{a}_{3} X_{3}+\dot{a}_{4} X_{4}+ \\
& \dot{a}_{11} X_{1}^{2}+\dot{a}_{22} X_{2}^{2}+\dot{a}_{33} X_{3}^{2}+\dot{a}_{44} X_{4}^{2}+ \\
& \dot{a}_{12} X_{1} X_{2}+\dot{a}_{13} X_{1} X_{3}+\dot{a}_{14} X_{1} X_{4}+ \\
& \dot{a}_{23} X_{2} X_{3}+\dot{a}_{24} X_{2} X_{4}+\dot{a}_{34} X_{3} X_{4}
\end{aligned}
$$

\section{RESULTS AND DISCUSSION}

\section{Response Surface Optimization}

Statistical optimization for biosurfactant production was carried out according to the CCD of RSM using Design expert software. The response, biosurfactant concentration was estimated for 30 experiments and represented in Table 2. The response data were subjected to regression analysis to estimate the regression coefficient. The estimated coefficients were presented in Table 3 and a second-order polynomial equation (final equation in terms of coded factors) (Eqn. 2) and final equation in terms of actual factors (Eqn.3) for biosurfactant production was constructed using the coefficients.

$$
\begin{aligned}
& +8.04+0.60 \mathrm{~A}+0.23 \mathrm{~B}-0.41 \mathrm{C}-0.23 \mathrm{D}-0.72 \mathrm{AB}+ \\
& \begin{aligned}
Y_{\text {Biosurfactant }\left(\frac{g}{L}\right)}= & 0.21 \mathrm{AC}+0.21 \mathrm{AD}-0.017 \mathrm{BC}+0.29 \mathrm{BD}+0.72 \mathrm{CD}+ \\
& 0.27 \mathrm{~A}^{2}-0.44 \mathrm{~B}^{2}-0.42 C^{2}+0.043 D^{2}
\end{aligned}
\end{aligned}
$$

\section{Final Equation in Terms of Actual Factors}

$$
\begin{aligned}
\mathrm{Y} \_\left(\text {Biosurfactan } \mathrm{t}\left(\frac{\mathrm{g}}{\mathrm{L}}\right)=\right. & 1.96086-0.014745 \times \text { Agarpowder } \\
& +1.95536 \times \text { Yeast extract }+224.80208 \\
& \times \mathrm{FeSO}_{4} 7 \mathrm{H}_{2} \mathrm{O}-52.13854 \times \mathrm{KH}_{2} \mathrm{PO}_{4} \\
& -0.018109 \times \text { Agarpowder } \times \mathrm{Yeast} \mathrm{extract} \\
& +1.04687 \times \text { Agarpowder } \times \mathrm{FeSO} 7 \mathrm{H}_{2} \mathrm{O} \\
& +0.10406 \times \text { Agarpowder } \times \mathrm{KH}_{2} \mathrm{PO}_{4} \\
& -0.84375 \times \text { Yeast extract } \times \mathrm{FeSO}_{4} .7 \mathrm{H}_{2} \mathrm{O} \\
& +1.47188 \times \text { YeastYeast extract } \\
& \times \mathrm{KH}_{2} \mathrm{PO}_{4}+720.62500 \times \mathrm{FeSO}_{4} .7 \mathrm{H}_{2} \mathrm{O} \\
& \times \mathrm{KH}_{2} \mathrm{PO}_{4}+0.000673177 \times(\mathrm{Agarpowder}) \\
& -0.11112 \times(\mathrm{Yeast} \text { extract })^{2}-4219.79167 \\
& \times\left(\mathrm{FeSO}_{4} .7 \mathrm{H}_{2} \mathrm{O}\right)^{2}+4.302081\left(\mathrm{KH}_{2} \mathrm{PO}_{4}\right)^{2}
\end{aligned}
$$

The adequacy of the model was checked using analysis of variance, and the results were shown in Table 3 . The model $\mathrm{F}=2.79$ implies the model is significant. There is only a $2.92 \%$ chance that a "model F-value" this large could occur due to noise. The high value of F-test for regression indicating that the model is fit well and can adequately explain the variation observed in biosurfactant concentration with the designed levels of variables. Probability value $(p<0.0500)$ is usually used to check the statistical significance of the parameters. Results represented in Table 3 explained that the individual effect of agar powder (A), agar powder*yeast extract (AB), $\mathrm{FeSO}_{4} \cdot 7 \mathrm{H}_{2} \mathrm{O} * \mathrm{KH}_{2} \mathrm{PO}_{4}(\mathrm{CD})$, and square effect of yeast extract $\left(\mathrm{B}^{2}\right)$, and $\mathrm{FeSO}_{4} \cdot 7 \mathrm{H}_{2} \mathrm{O}\left(\mathrm{C}^{2}\right)$ was found significant in the production of biosurfactant. $\mathrm{R}^{2}$ value was observed as 0.7222 , and this value shows that the model was fitted for $72.2 \%$ of biosurfactant production. These results showed that the model chosen can satisfactorily explain the linear effects and square effects of the variables selected for the biosurfactant production.

Figure 1 represents the combined effect of agar powder and yeast extract, and maximum biosurfactant production $(10.2 \mathrm{~g} / \mathrm{L})$ was observed at the low level of yeast extract $(4.53 \mathrm{~g} / \mathrm{L})$. There was a significant increase in the product concentration when agar powder concentration increased from $30 \mathrm{~g} / \mathrm{L}$ to $70 \mathrm{~g} / \mathrm{L}$ Makkar and Cameotra; Kumar et al. ${ }^{[21,22]}$ reported that agar powder was most suitable carbon source for biosurfactant production by glycolipid among the other carbohydrates studied. Several researchers concluded that the presence of yeast extract in low concentration increases the biosurfactant synthesis. ${ }^{[22,23]}$ Supplementation of yeast extract $(4 \mathrm{~g} / \mathrm{L})$ in the production medium was sufficient for enhancing biosurfactant production as the amino acids are required for the formation of the glycolipid biosurfactant by A. xylos GSR21 Casas and García-Ochoa; Kumar et al. ${ }^{[22,24]}$ also reported that a low level of yeast extract enhances the biosurfactant production. 
Figure 2 demonstrated that increase in both agar powder and $\mathrm{FeSO}_{4} \cdot 7 \mathrm{H}_{2} \mathrm{O}$ improves the biosurfactant production. It was observed that the $\mathrm{FeSO}_{4} \cdot 7 \mathrm{H}_{2} \mathrm{O}$ in the medium plays a significant role in productivity. When agar powder concentration increases from low to high level, the productivity was also increased whereas an increase in concentration of $\mathrm{KH}_{2} \mathrm{PO}_{4}$ does not show any impact in the biosurfactant production [Figure 3].

From Figure 4, it was observed that the production of biosurfactant decreased when the yeast extract increased from low to high level stating that $4.53 \mathrm{~g} / \mathrm{L}$ is sufficient for optimum productivity, whereas the productivity increased when the concentration of $\mathrm{FeSO}_{4} \cdot 7 \mathrm{H}_{2} \mathrm{O}$ increased from low to high level.

In Figure 5, biosurfactant production was decreased when yeast extract concentration increased from low to high whereas static condition is prevailed in $\mathrm{KH}_{2} \mathrm{PO}_{4}$ indicating the contribution for biosurfactant production by $\mathrm{KH}_{2} \mathrm{PO}_{4}$ is minimum. It is observed that the productivity of biosurfactant increased when the concentration of ferrous sulfate increased from low to high [Figure 6].

Point prediction tool of design expert software was used to determine the optimal level of each variable in the process. The maximum biosurfactant concentration $(10.20 \mathrm{~g} / \mathrm{L})$ was predicted by the software at an optimal
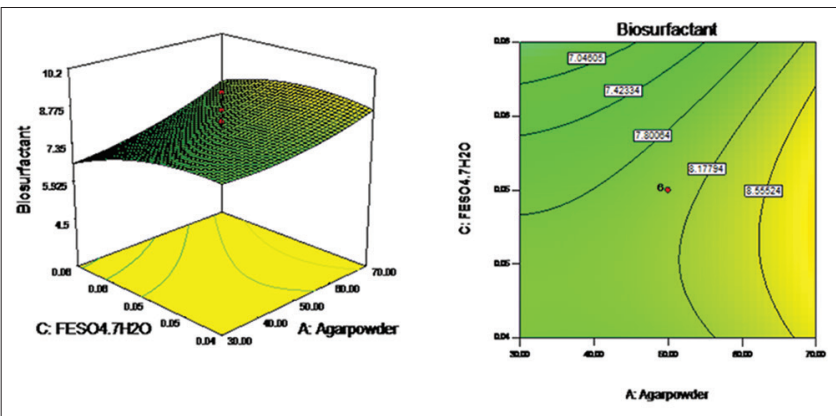

Figure 2: Three-dimensional and contour surface plots showing the mutual effect between pair of variables agar powder $(\mathrm{A})$ and $\mathrm{FeSO}_{4} \cdot 7 \mathrm{H}_{2} \mathrm{O}(\mathrm{C})$ on biosurfactant production
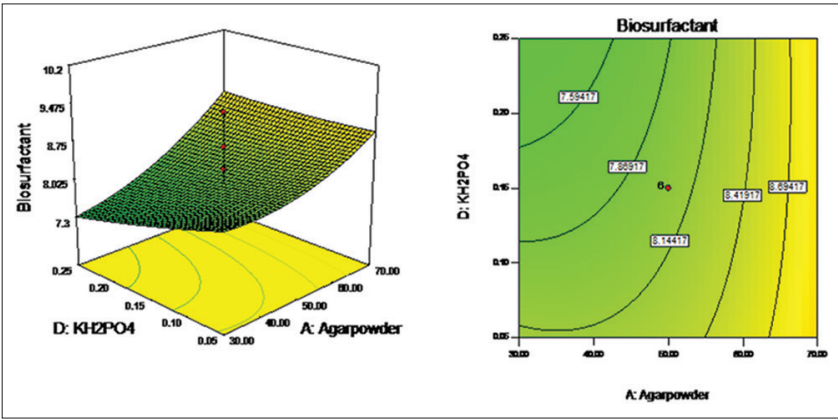

Figure 3: Three-dimensional and contour surface plots showing the mutual effect between pair of variables agar powder $(\mathrm{A})$ and $\mathrm{KH}_{2} \mathrm{PO}_{4}(\mathrm{D})$ on biosurfactant production level of agar powder $-90 \mathrm{~g} / \mathrm{L}$, yeast extract $-5 \mathrm{~g} / \mathrm{L}$, $\mathrm{FeSO}_{4} \cdot 7 \mathrm{H}_{2} \mathrm{O}-0.055 \mathrm{~g} / \mathrm{L}$, and $\mathrm{KH}_{2} \mathrm{PO}_{4}-0.15 \mathrm{~g} / \mathrm{L}$.

\section{Model Validation}

To check the accuracy of the predicted model, experiments were carried out at the predicted optimal concentration of agar powder $-90 \mathrm{~g} / \mathrm{L}$, yeast extract $-5 \mathrm{~g} / \mathrm{L}$, $\mathrm{FeSO}_{4} \cdot 7 \mathrm{H}_{2} \mathrm{O}-0.055 \mathrm{~g} / \mathrm{L}$, and $\mathrm{KH}_{2} \mathrm{PO}_{4}-0.15 \mathrm{~g} / \mathrm{L}$. In the validation experiment, maximum biosurfactant concentration of $9.69 \mathrm{~g} / \mathrm{L}$ was obtained. The time course profile of biosurfactant and biomass production by $A$. xylos GSR21 at predicted optimal level of the medium components is shown in Figure 7. The validation result indicates that predicted model was fitted $96.9 \%$ with the experimental results.

\section{CONCLUSION}

RSM was successfully applied to optimize the four media components to enhance the biosurfactant production. Four variables (agar powder, yeast extract, $\mathrm{FeSO}_{4} .7 \mathrm{H}_{2} \mathrm{O}$, and $\mathrm{KH}_{2} \mathrm{PO}_{4}$ ) were optimized according to the $\mathrm{CCD}$ of RSM. Surface plots were made and the optimized values obtained for the maximum production of biosurfactant were agar powder $-90 \mathrm{~g} / \mathrm{L}$, yeast extract $-5 \mathrm{~g} / \mathrm{L}$,

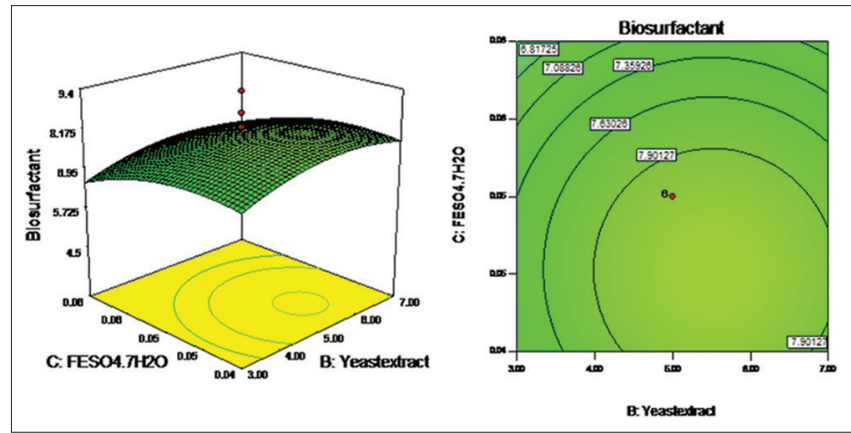

Figure 4: Three-dimensional and contour surface plots showing the mutual effect between pair of variables yeast extract $(\mathrm{B})$ and $\mathrm{FeSO}_{4} \cdot 7 \mathrm{H}_{2} \mathrm{O}(\mathrm{C})$ on biosurfactant production
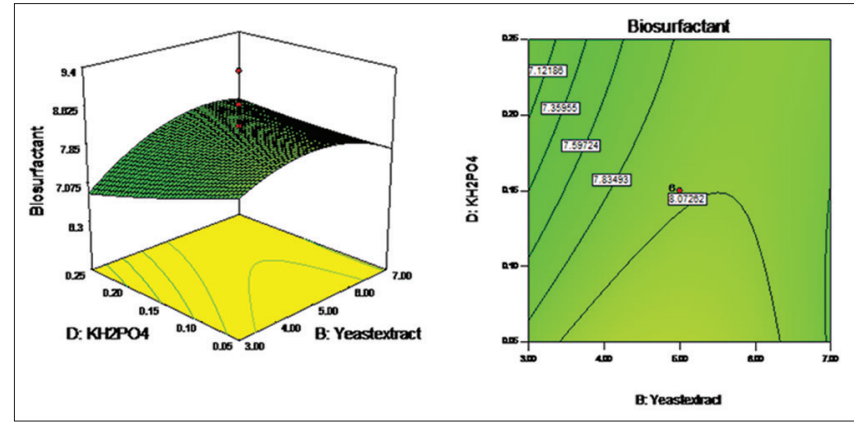

Figure 5: Three-dimensional and contour surface plots showing the mutual effect between pair of variables yeast extract $(\mathrm{B})$ and $\mathrm{KH}_{2} \mathrm{PO}_{4}(\mathrm{D})$ on biosurfactant production 


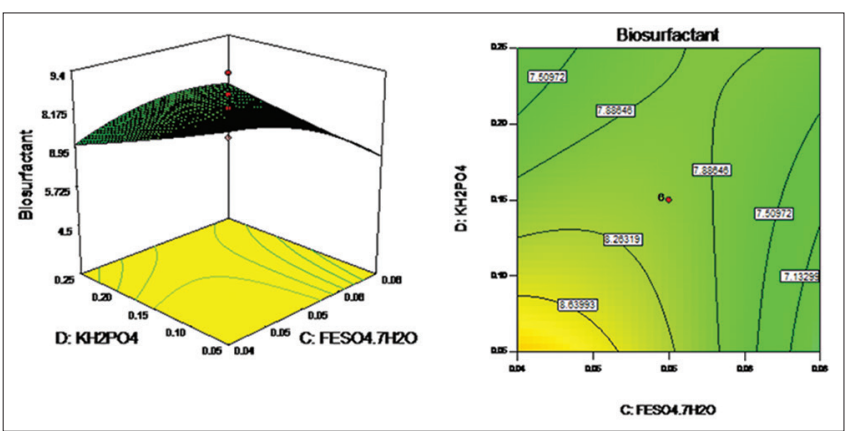

Figure 6: Three-dimensional and contour surface plots showing the mutual effect between pair of variables $\mathrm{FeSO}_{4} \cdot 7 \mathrm{H}_{2} \mathrm{O}(\mathrm{C})$ and $\mathrm{KH}_{2} \mathrm{PO}_{4}(\mathrm{D})$ on biosurfactant production

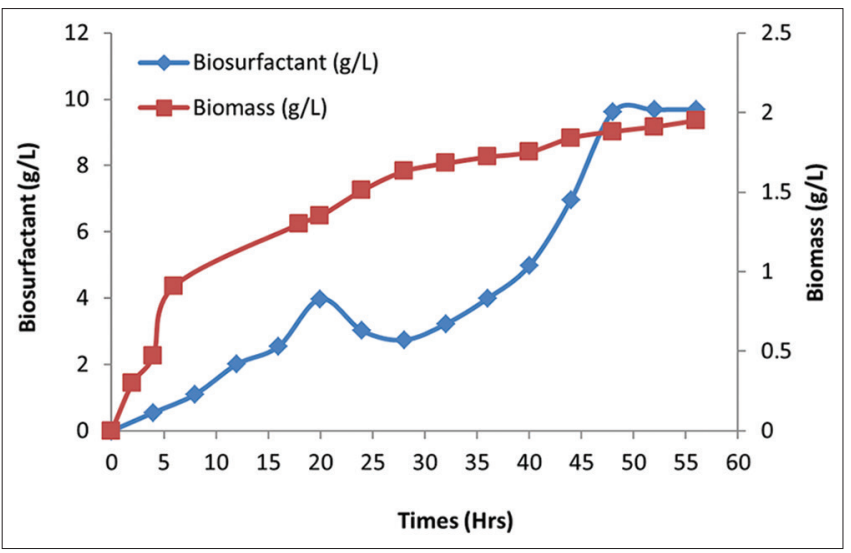

Figure 7: Time course profile of biosurfactant and biomass production by Achromobacter xylos GSR 21 predicted the optimal level of the selected medium components in the validation experiment

$\mathrm{FeSO}_{4} \cdot 7 \mathrm{H}_{2} \mathrm{O}-0.055 \mathrm{~g} / \mathrm{L}$, and $\mathrm{KH}_{2} \mathrm{PO}_{4}-0.15 \mathrm{~g} / \mathrm{L}$. Validation of the experiment was performed, and it indicates that the model was well fitted with the experimental results. Application of RSM illuminates the optimal levels for enhanced production of biosurfactant with less experimental runs and interaction effects of the variables.

\section{AUTHORS' CONTRIBUTIONS}

GSR and BM conceived the study. GSR carried out the laboratory analysis. GSR, BM, and RSR participated in the study design and coordination and drafting of the manuscript. All authors read and approved the final manuscript.

\section{ACKNOWLEDGMENTS}

The authors are grateful to Sri. K Satyanarayana Garu, president, K L University for supporting this research work. The authors are also thankful to Prof. L S S Reddy, Vice Chancellor for giving permission and Dr. K. Srinivasulu, HOD-BT for his encouragement during this work.

\section{COMPETING INTEREST}

The authors declare that they have no competing interests.

\section{REFERENCES}

1. Bas D, Boyaci IH. Modeling and optimization I: Usability of response surface methodology. J Food Eng 2007;78:836-45.

2. Desai JD, Banat IM., Microbial production of biosurfactants and their commercial potential. Microbiol Mol Biol Rev 1997;61:41-64.

3. Mulligan CN. Environmental application for biosurfactants. Environ Poll 2005;133:183-98.

4. Singh A, Van Hamme JD, Ward OP. Surfactants in microbiology and biotechnology: Part 2. Application aspects. Biotechnol Adv 2007;25:99-121.

5. Neto DM, Meira JA, de Araujo JM, Mitchel DA, Krieger N. Optimization of the production of rhamnolipids by Pseudomonas aeruginosa UFPEDA 614 in solid-state culture. Appl Microbiol Biotechnol 2008;81:441-8.

6. Mohan PK, Mukhla G, Yanful EK. Biokinetics of biodegradation of surfactants under aerobic, anoxic and anaerobic conditions. Water Res 2006;40:533-40.

7. Ghojavand H, Vahabzadeh F, Mehranian M, Radmehr M, Shahraki KA, Zolfagharian $\mathrm{F}$, et al. Isolation of thermotolerant, halotolerant, facultative biosurfactant producing bacteria. Appl Microbiol Biotechnol 2008;80:1073-85.

8. Hickey AM, Gordon M, Dodson ADW, Kelly CT, Doyle EM. Effect of surfactants on fluoranthene degradation by Pseudomonas alcaligenes PA-10. Appl Microbiol Biotechnol 2007;74:851-6.

9. Abbasi H, Sharafi H, Alidost L, Bodagh A, Zahiri HS, Noghabi KA. Response surface optimization of biosurfactant produced by Pseudomonas aeruginosa MA01 isolated from spoiled apples. Prep Biochem Biotechnol 2013;43:398-414.

10. Guerra de Oliveira J, Garcia-Cruz CH. Properties of a biosurfactant produced by Bacillus pumilus using vinasse and waste frying oil as alternative carbon sources. Braz Arch Biol Technol 2013;56:155-60.

11. Priya R, Kumar SS, Gupta R., Concomitant production and downstream processing of alkaline protease and biosurfactant from Bacillus licheniformis RG1: Bioformulation as detergent additive. Process Biochem 2005;40:3352-9.

12. Sanket J, Chirag B, Anjana JD. Production of biosurfactant and antifungal compound by fermented food isolate Bacillus subtilis 20B. Bioresour Technol 2008;99:4603-8.

13. Besson F, Michel G. Biosynthesis of iturin and surfactin by Bacillus subtilis. Evidence for amino acid activating enzymes. Biotechnol Lett 1992;14:1013-8. 
14. Sandrin C, Peypoux F, Michel G. Coproduction of surfactin and iturin a lipopeptides with surfactant and antifungal properties by Bacillus subtilis. Biotechnol Appl Biochem 1990;12:370-5.

15. Chakravarti R, Sahai V. Optimization of compactin production in chemically defined production medium by Penicillium citrinum using statistical methods. Process Biochem 2002;38:481-6.

16. Haaland PD. Experimental Design in Biotechnology. New York: Dekker; 1989.

17. Myers RH, Montgomery DC. Response Surface Methodology, Process and Product Optimization using Design Experiments. New York: John Wiley \& Sons;

18. Khayati G, Gilani HG, Kazemi M. The effect of olive cake types on lipase production by isolated Rhizopus sp. And process statistical optimization. J Biosci Biotechnol 2013;2:45-55.

19. Tamilarasan K, Kumar MD. Optimization of medium components and operating conditions for the production of solvent-tolerant lipase by Bacillus sphaericus MTCC 7542. Afr J Biotechnol 2011;10:15051-7.
20. Kim H, Yoon B, Lee C, Suh H, Katsuragi T, Tani Y., Production and properties of a lipopeptide biosurfactant from Bacillus subtilis C9. J Ferm Bioeng 1997;84:41-6.

21. Makkar RS, Cameotra SS. Effects of various nutritional supplements on biosurfactant production by a strain of Bacillus subtilis at $45^{\circ} \mathrm{C}$. J Surf Deter 2002;5:11-8.

22. Kumar SS, Sharmila G, Muthukumaran C, Tamilarasan K, Gopinath M. Statistical optimization of critical medium components for biosurfactant production by Bacillus subtilis. J Bio Sci Biotechnol 2015;4:123-9.

23. Gandhimathi R, Kiran GS, Hema TA, Selvin J, Raviji TR, Shanmughapriya S. Production and characterization of lipopeptide biosurfactant by a sponge-associated marine actinomycetes Nocardiopsis alba MSA10. Bioprocess Biosyst Eng 2009;32:825-35.

24. Casas JA, García-Ochoa F. Sophorolipid production by Candida bombicola: Medium composition and culture methods. J Biosci Bioeng 1999;88:488-94.

Source of Support: Nil. Conflict of Interest: None declared. 